\title{
PHM is grieving for the loss of Amit but his legacy is a renewed commitment towards a better, more caring world
}

\author{
MSP está de luto pela perda de Amit, mas seu legado é um \\ compromisso renovado em direção a um mundo melhor e mais \\ solidário
}

David Legge ${ }^{\mathbf{1 , 2}}$

DOI: $10.1590 / 0103-110420205123$

1 La Trobe University Melbourne, Australia.

dlegge@phmovement.org

2 People's Health Movement (PHM) -

Melbourne, Australia.
AMIT SENGUPTA DROWNED IN A SWIMMING ACCIDENT IN GOA on the 28 November 2018, just days after the fourth People's Health Assembly (PHA) in Savar, in Bangladesh, which Amit had been instrumental in organising. He was just 60 years of age.

Amit trained originally as a doctor and continued to practice throughout his career, albeit on a part-time basis. However, his main vocation was as a social justice activist, working for a better, more caring world.He was involved in a great many struggles and organisations and while we highlight some specific involvements, they should be understood as representing a wider range of engagements.

From the early 1980s Amit was active in the people's science movement (starting with the Delhi Science Forum and later the All India People's Science Network, of which he was national secretary from 2000-2004). It was in this context that he was involved in the response to the Bhopal tragedy (described further in this issue; see Raghunandan eJayaprakash) ${ }^{\mathbf{1}}$. Amit was very involved in the rational use of medicines movement in India from the 1980s and subsequently the All India Drug Action Network as his advocacy extended to encompass access to medicines, patent law, research and development and latterly biologicals. Building on his work in science, medicines and a range of different struggles, Amit was closely involved in the formation of People's Health Movement (PHM) at the first PHA in Savar in December 2000. Following PHA Amit's main commitment was to PHM in India (Jan SwasthyaAbhiyan) but he was increasingly involved in PHM at the global as well as national levels. Amit was active in the leadership of the World Social Forum from the early 2000s and played a major role in coordinating civil society contributions globally to the work of the World Health Organization (WHO) Commission on the Social Determinants of Health (which reported in 2008). In 2009 Amit took on the role of associate coordinator of PHM with particular responsibility for producing Global Health Watch and coordinating WHO Watch. However, Amit was across the whole agenda of PHM: pointing out the risks; arguing new directions; bringing the doubters along. At several important junctures Amit played a critical role in PHM's strategic thinking, including the structural reforms which have led to the young, diverse and vibrant steering council now guiding the network. 
PHM's loss, with the passing of Amit,invites us to reflect on the nature of leadership in the social movement context: the level of trust which he was accorded and the power of the inspiration which he projected.

From close colleagues to those with only occasional contact, we learned that we could rely on Amit for insightful explanations and far reaching strategic guidance. We learned to trust his advice because of his track record in getting it right, his wide-ranging and deep expertise, the clarity of his thought and exposition, the integrity with which he lived his life and the loving reach of his relationships.

Amit projected inspiration; he inspired us to find more and to go further. We were inspired by his moral clarity (naming the world's wrongs clearly and unambiguously); by his own personal morality (living his principlesfirmly); by his achievements and the efforts that they reflected; by the generosity of his

\section{Reference}

1. Raghunandan D, Jayaprakash ND. Bhopal Gas Disaster: Delhi Science Forum and People's Science Move- teaching and mentoring and by his commitment to research and evidence.

Amit believed that 'another world is possible' and saw the collective agency of people's movements as critical to achieving that more caring world. This was not just about science or medicines or health; he projected a vision of people's movements coming together across issues, boundaries and differences; working together for a better world. The commitment of the grass roots activists whose work is reported in this issue of 'Saúde em Debate' provides a glimpse of thevision which inspired Amit; and of the vision which Amit projected and which has inspired PHM.

\section{Collaborator}

Legge D (0000-0002-4552-1470)* is responsible for drafting the manuscript. ment in India - In memory of Amit Sengupta. Saúde debate. 2020; 44(spel). (in press). 